\title{
STRUCTURAL EVOLUTION OF BODE SAADU AREA, SOUTHWESTERN NIGERIA
}

\author{
C. T. Okonkwo \\ Department of Geology, University of Ilorin P.M.B. 1515, Ilorin, Nigeria. \\ E-mail cokonkwo@unilorin.edu.ng
}

\begin{abstract}
The Bode Saadu area comprises metasedimentary and metaigneous rocks which have been subjected to polyphase deformation and have subsequently been intruded by post-tectonic granitic rocks of probably Pan-African $(600 \pm 150 \mathrm{Ma})$ age. Five phases of post-sedimentary tectonic deformation have been recognized in the rocks of this area. The first phase was associated with the development of the regional foliation, S1, and tight to isoclinal minor folds. The second phase involved heterogeneous deformation which gave rise to ductile shear zones, extensional and contractional faults. Second phase structures also include minor asymmetrical folds which deform $S 1$ and SO. The third phase produced the dominant major folding on approximately $N$-S axis including the major Bode Saadu antiform. The fourth phase gave rise to open folds and crenulation of the earlier structures. Late brittle structures include transcurrent faults, both dextral and sinistral, which occasionally occurred in conjugate sets under generally $N$-S trending, maximum conpressive stress.
\end{abstract}

\section{INTRODUCTION}

The Bode Saadu area forms part of the southwestern sector of the Nigerian basement complex which comprises Archean and Proterozoic rocks bearing the imprints of the Liberian $(2700 \pm 200 \mathrm{Ma})$, Eburnean $(2000 \pm 200 \mathrm{Ma})$ orogenic events (Oversby, 1976). This basement was a zone of basement reactivation and orogenesis during the Pan-African (600 $\pm 150 \mathrm{Ma}$ ) event (Van Breemen et al. 1977, Fitches et al. 1985). The existence of the Kibaran (1100 \pm 200Ma) event in Nigeria claimed by some workers (e.g. Ogezi 1977, Ekwueme 1987) on the basis of some Rb/Sr dates on metamorphic rocks is not generally accepted.

Recent studies (Okonkwo 1992a, 1996) in the Jebba area to the north has demonstrated the polyphase nature of the deformation in this internal zone of the Pan-African orogenic belt which involved ductile folding, shear zones, thrust faulting and nappe formation.

This paper documents the results of recent studies in the Bode Saadu area and discusses the structural history of the basement rocks in the area.

\section{LITHOSTRATIGRAPHY}

The Bode Saadu area is underlain by metasedimentary and metaigneous rocks which have been intruded by late- to post-tectonic granitic rocks of probable Pan-African age. As a result of polyphase deformation and metamorphism associated with migmatisation the lithostratigraphic sequence is difficult to establish with certainty. However, observable lithological and structural (including crosscutting) relationships enable a provisional lithostratigraphic classification to be recognised.

\section{Migmatitic Gneiss.}

This lithostratigraphic unit outcrops in the western and eastern belts of the area (Fig.1). It comprises a sequence of variably migmatised gneisses with concordant quartzofeldpathic segregations and bands (Fig.2a). Major mineral constituents of this unit are quartz, plagioclase feldspar, biotite and microcline. Locally, it may contain significant amounts of hornblende.

The nature of the paleosome is variable and it seems to include both metasedimentary and metaigneous rocks. The pervasive migmatisation appears to be the product of both subsolidus metamorphic segregation (Sawyer and Robin 1986) and the injection of granitic material. Locally, the gneiss may contain thin concordant to discordant bands of metabasic intrusions (Fig.2a). 


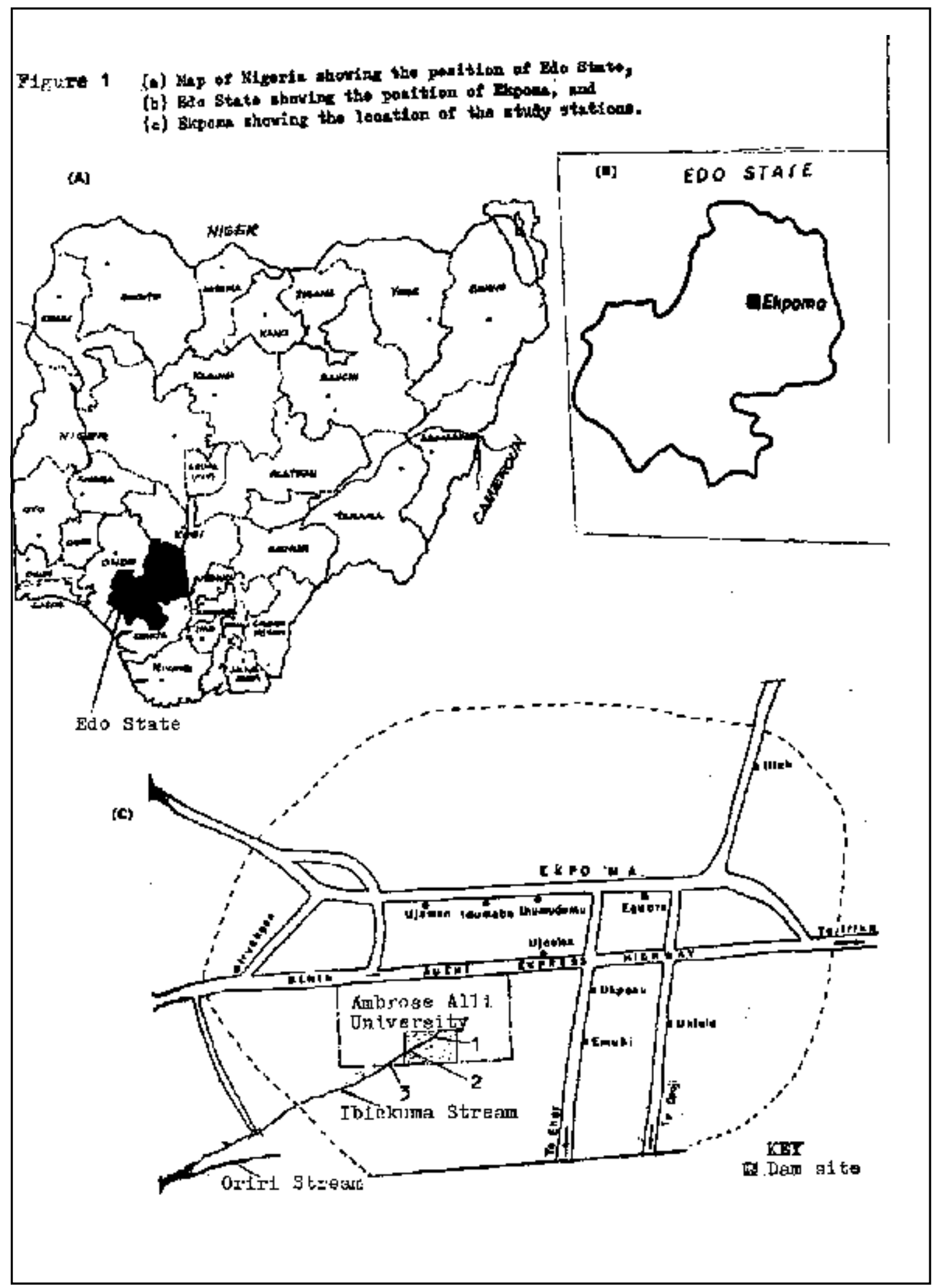

Fig.1. Geological map of Bode Saadu area 


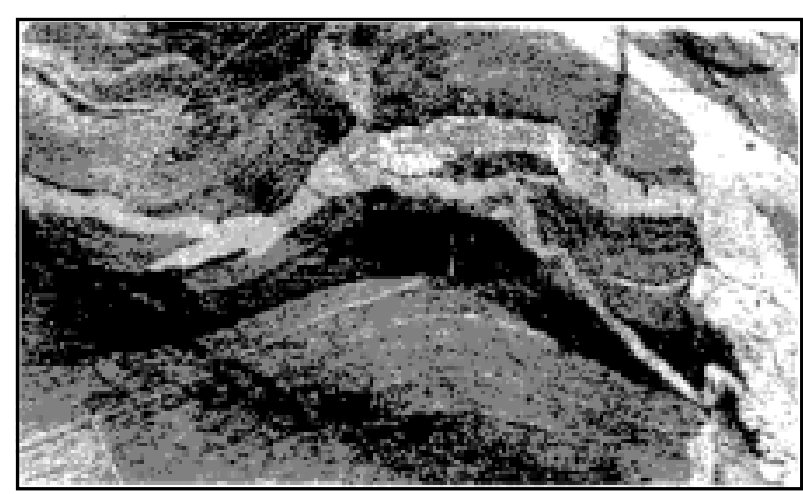

Fig. 2a. Migmatitic gneiss showing cross-cutting metabasic and granitic dykes

\section{Metagreywacke}

A sequence of grey, quartz -, plagioclase- and biotitebearing psammitic rocks is concordantly interbanded with the migmatitic gneisses (Fig. 1) in a N-S trending belt where it locally occupies a belt between the migmatitic gneisses and the Quartzite in the north and is intercalated with the Quartzite in the south. The biotite content of the metagreywacke varies from horizon to suggesting relict grading (Fig. 2b). Also more pelitic bands may be interstratified with more psammitic ones (Fig.3a) indicating relict sedimentary lithological variations (Pettijohn 1975).

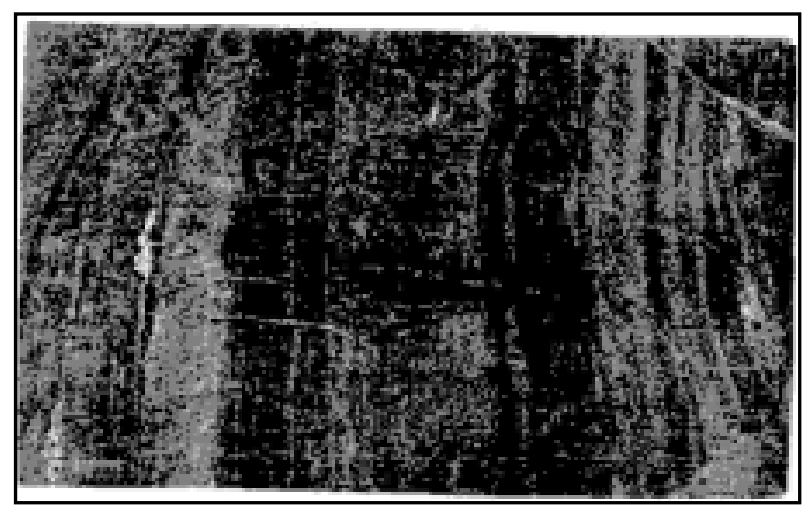

Fig. 2b. Metagreywacke showing quartz-feldspar-rich and more biotite-rich bands

The thicker quartz-feldspar rich metagreywackes locally contain thin greyish bands rich in plagioclase, epidote and calcite which are similar to diagenetic calc-silicate bands (cf. Winchester 1975, Okonkwo 1992b). Locally the metagreywackes may also contain preserved sedimentary and soft-sediment deformation structures such as crossbedding, convolute folds and laminations (Okonkwo 1995).

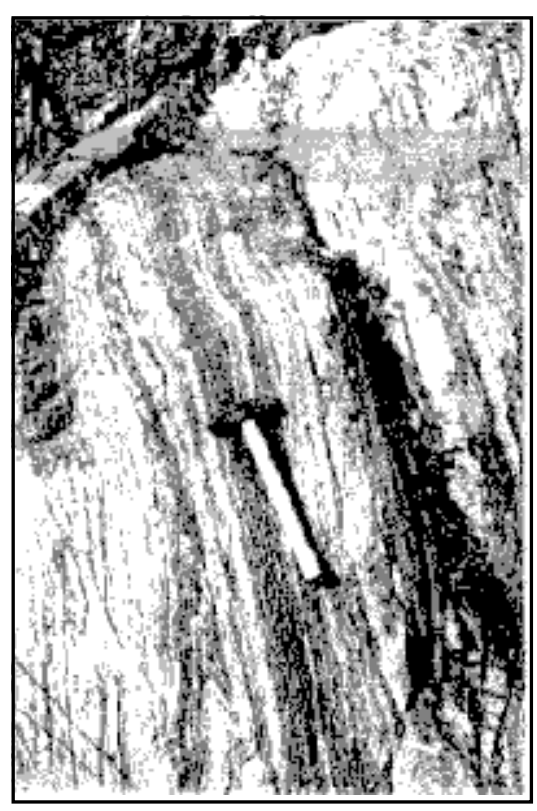

Fig. 3a. Metagreywacke showing psammitic bands interstratified with more pelitic ones. Bottom half of the picture shows a second phase asymmetrical fold

Medium and thinly-bedded metagreywackes may be locally more intensely deformed and magmatised (Fig. 3b)) leading to the obliteration of primary sedimentary features.

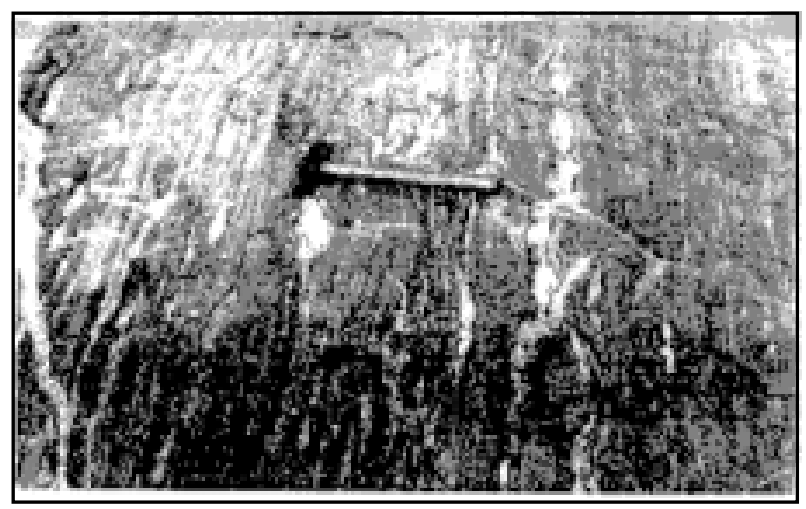

Fig.3b.More intensely deformed and migmatised metagreywacke

Concordant bands of amphibolite, $10-20 \mathrm{~cm}$ thick, containing hornblende, plagioclase, minor quartz and biotite are locally intercalated within the metagreywackes. Also, locally, concordant and discordant bands of metabasic intrusions $10 \mathrm{~cm}$ to $90 \mathrm{~cm}$ thick occur in the metagreywackes (Fig.4a). These intrusions contain biotite, plagioclase, magnetite, epidote and, apatite and are chemically similar to within-plate alkaline basalts (Okonkwo and Winchester 1995). 


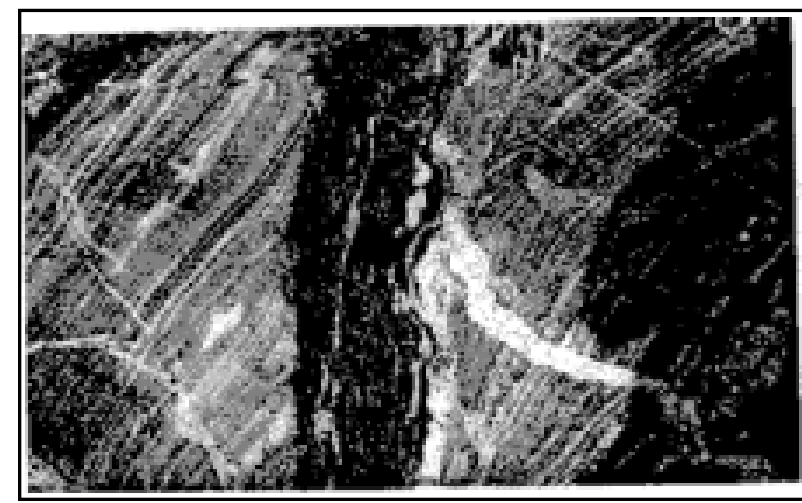

Fig. 4a Metabasic dyke in metagreywacke plots of poles to foliations

\section{Quartzite}

This unit mainly occupies a N-S trending central belt extending from Biribiri in the north to Bode Saadu in the south (Fig. 1). The quartize is thinly-to thickly bedded and locally micaceous. It also occurs as thick intercalations in the migmatitic gneisses (Fig. 1).

\section{Post-tectonic Granitic rocks}

Intruding and cross-cutting the metamorphic rocks of this area are generally undeformed granitic rocks varying in composition from granites to granodiorites.

These rocks which are similar to late Pan-African granitic rocks described and dated from several places in Nigeria (Van Breemen et al. 1977, Fitches et al. 1985, Rahaman 1988) often form thin bands in the older rocks and more mappable outcrops in some areas (Fig. 1)

\section{STRUCTURALDEVELOPMENT}

Five phases of post-sedimentary tectonic deformation have been recognised in the rocks of this area; these are described below.

\section{First Deformation}

The earlier planar structure, S1, is generally parallel to the bedding S0 defined by lithological variation in the metasedimentary rocks especially the metagreywackes (Fig. 3a). In the migmatitic gneisses the $\mathrm{S} 1$ foliation is defined by both a grain shape alignment of biotite, hornblende and feldspar and gneissic banding due to interbanding of dark, mafic and light-coloured, felsic bands (Fig. 2a). Under early deformation stress and ambient temperature conditions subsolidus metamorphic segregation (Sawyer and Robin 1986) may have formed layer-parallel quartzofelspathic bands in the metagreywackes and migmatitic gneisses. Later, another phase of migmatisation by lit-parlit injection of granitic material along pre-existing anisotropies such as S1 occurred. This granitic mateiral is inferred to be derived from early members of the granitic suite.

Early lineations are defined by grain shape alignment on SI surfaces which now show a wide scatter (Fig. 4b) as a result of variable rotations by subsequent deformation events. First phase minor folds are tight to isoclinal folds of the migmatitic leucosome in the migmatitic gneiss (Fig. $5 a)$. The dominant foliation, $\mathrm{S} 1$, is axial planar to these minor folds. No major folds of this generation have been recognised.

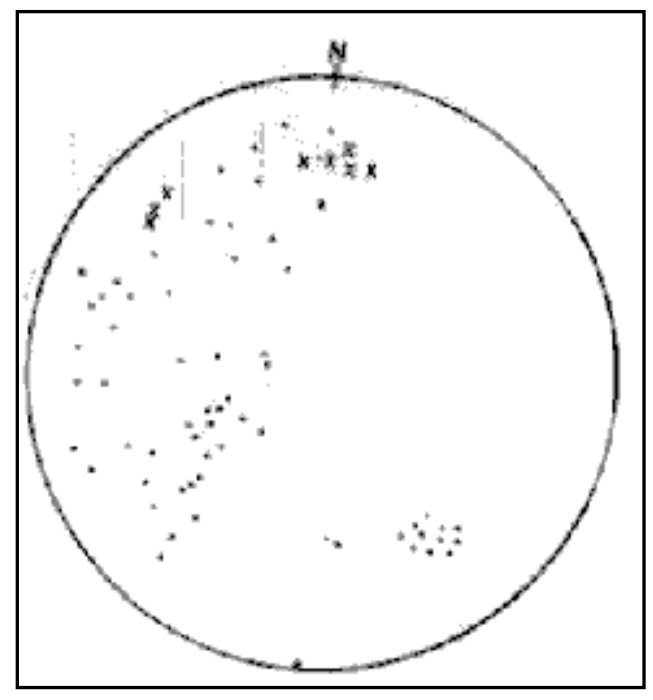

Fig. 4b. Equal area stereographic and lineations. (dots=foliations; crosses=lineations)

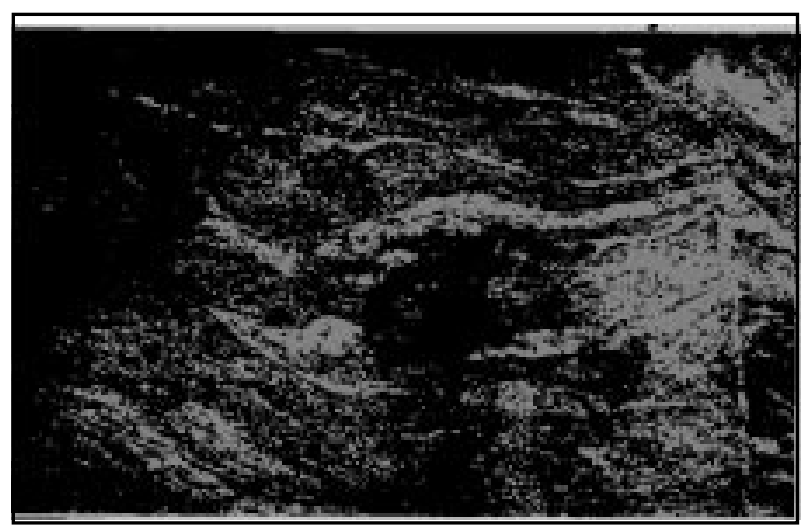

Fig. 5a. First phase isoclinal fold in migmatitic gneiss 
Feldspathic material in the zone (Fig. 5b) and a local cleavage (foliation) (S2) cross-cutting S1. In many cases, ductility enhanced by the high-temperature conditions at mid-crustal level ensured that no clear-cut fractures were developed. Other evidences of extensional strain found in the rocks include boudinage of felsic bands in the gneisses and of quartzo-feldspathic, calc-silicate and metabasic bands in the metagreywackes (Fig. 6a).

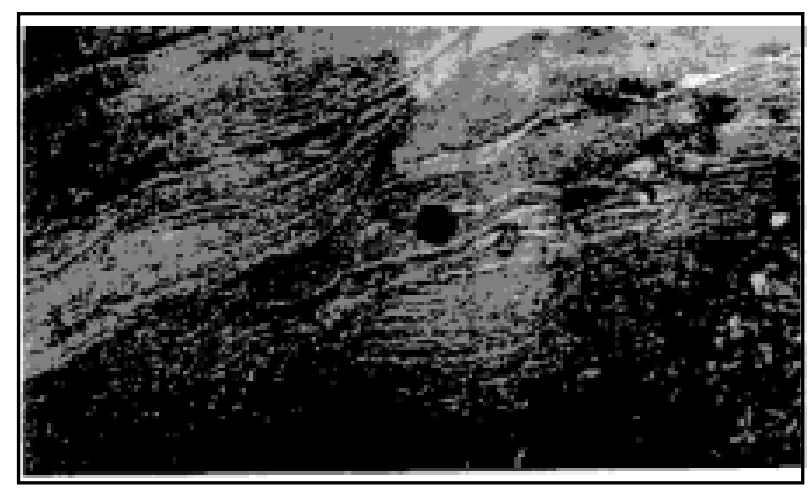

Fig. 5b. Extensional shear zone in the migmatitic gneiss marked by quartzo-feldspathic veining

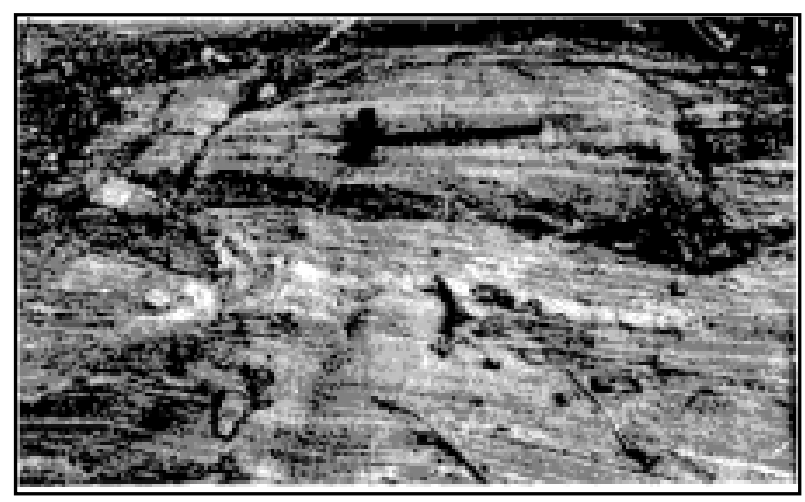

6a. Extensional shear zone (bottom left of picture) associated with a later contraction fault in the metagreywacke. It also shows a boudinaged metabasic dyke later shortened by the contractional fault

Second phase minor folds deform the S0/S1 fabrics in the rocks. These are generally tight, asymmetrical folds with profiles of similar folds (Fig. 3a). They may be locally associated with contractional faults or semi-ductile shears. The vergence of these folds indicates that they are parasitic to a major, recumbent fold.

The contractional faults associated with some minor second phase asymmetrical folds (Fig. 6a) clearly deform earlier fabric which had been subjected to extensional strains and therefore indicate that extension generally predated contraction, probably in a progressive deformational sequence (Ramsay and Huber 1987).

Locally, foliation in the metabasic dykes (S2) cross-cuts the gneissic banding and S0/S1 in the metagreywackes (Fig. 4a). It seems that because of strain localization, displacements took place later within some of the dykes. This suggests that at this time the dykes were less competent than the host rocks.

\section{Third Deformation}

This event was associated with the development of minor asymmetrical folds which deform and crenulate S1, they are generally tight to open folds. One major antiform (Fig.1) with an approximately $\mathrm{N}-\mathrm{S}$ axis has been recognised on the basis of the orientations of S0/S1 surfaces as well as the vergence of minor third phase folds.

The asymmetrical distribution of lithostratigraphic units about the axial trace of this fold indicates that it folded sequences which had been already deformed by major recumbent folds. Equal area stereographic plots of poles to $\mathrm{S} 1$ (Fig. 4b) show a wide scatter also reflecting polyphase deformation and rotation of the planes and lineations. This major fold is the southward continuation of the major Jebba Antiform (Okonkwo 1992a).

\section{Fourth Deformation}

This event gave rise to open folds in the rocks which crenulated earlier structures. In the migmatitic genisses, the late discordant metabasic dyke is deformed along with the early gneissic banding (Fig. 2a). D4 minor folds also deformed early pegmatite bands in the older rocks.

\section{Late Deformation}

Late brittle tectonics include transcurrent faults, both dextral and sinistral, which locally occur in conjugate sets. Conjugate fault sets form with their acute bisectrix subparallel to the maximum compressive stress $(\sigma 1)$ (Ramsay and Huber, 1987), the $\sigma 1$ principal stress plane being parallel to the earth's surface. The fault planes are mostly vertical in this case and the azimuth of $\sigma 1$ determined from analysis of the fault orientation data (Fig. 6b) is approximately N-S. 


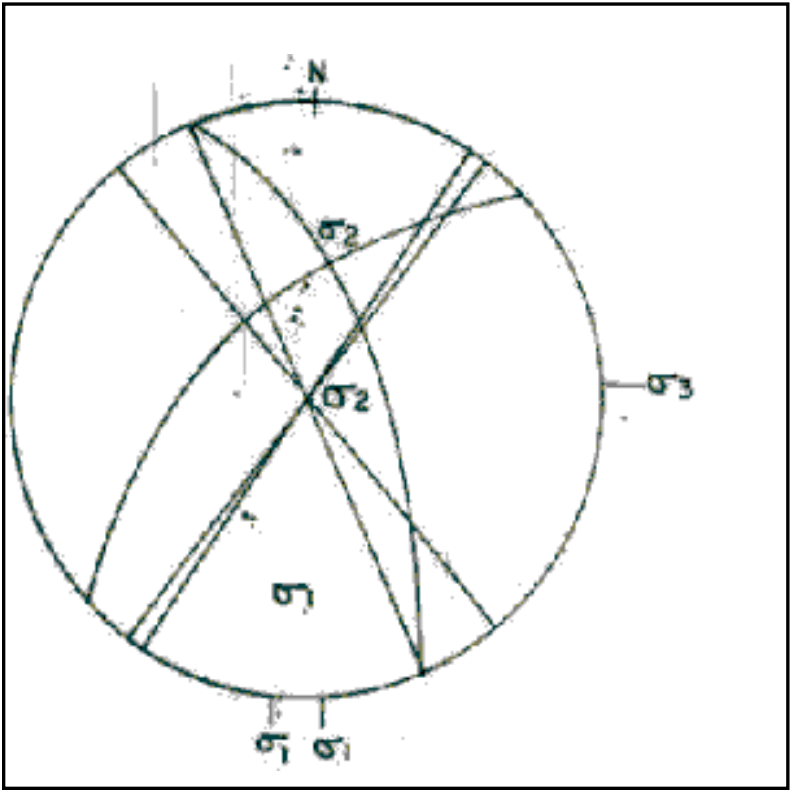

Fig. 6b. Stereographic analysis of conjugate fault sets orientation data showing the orientations of the principal stresses

\section{DISCUSSIONAND REGIONAL CORRELATIONS}

Ductile shear zones, thrusts and recumbent folds are the dominant features of internal zones of orogenic belts (Cooper 1981, Ramberg 1981, Alsop 1994). In the Bode Saadu area, these structures were commonly developed during the second deformation phase and reflect both the variations in strain gradients and the differences in the mechanical responses of the rocks during deformation.

The existence of major recumbent folds (fold nappes) has been documented from other parts of southwestern Nigeria, e.g., in the Ife-Ilesha area (Boesse et al. 1989, Caby 1989) and the Jebba areas (Okonkwo 1996). Other workers have also recognised early, tight to isoclinal recumbent folds on a macroscropic scale from other parts of the Nigeria basement complex: Isanlu area (Annor et al.1986), Okene and Igarra area (Annor 1998), Maru and Birnin-Gwari areas (Fitches et al. 1985). This recumbent folding is attributable to non-coaxial deformation associated with progressive simple shear (Alsop 1994, Annor et al. 1986, Ramsay et al. 1983).

The major folding associated with the third phase in Bode Saadu area is similar in orientation and style to the main folding event recognised as F2 in other parts of the Nigerian basement Complex (Fitches et al, 1985, Annor et al. 1996, Annor 1998).

The age of the recumbent folding the Bode Saadu area is not known; however, Caby (1989) has argued that the nappe formation and thrusting in southwestern Nigeria is of PanAfrican age and is coeval with similar events in central Hoggar (Algeria) to the north, with ages bracketed between 629 and $613 \mathrm{Ma}$ (U-Pb on zircons, Bertrand et al. 1986). In

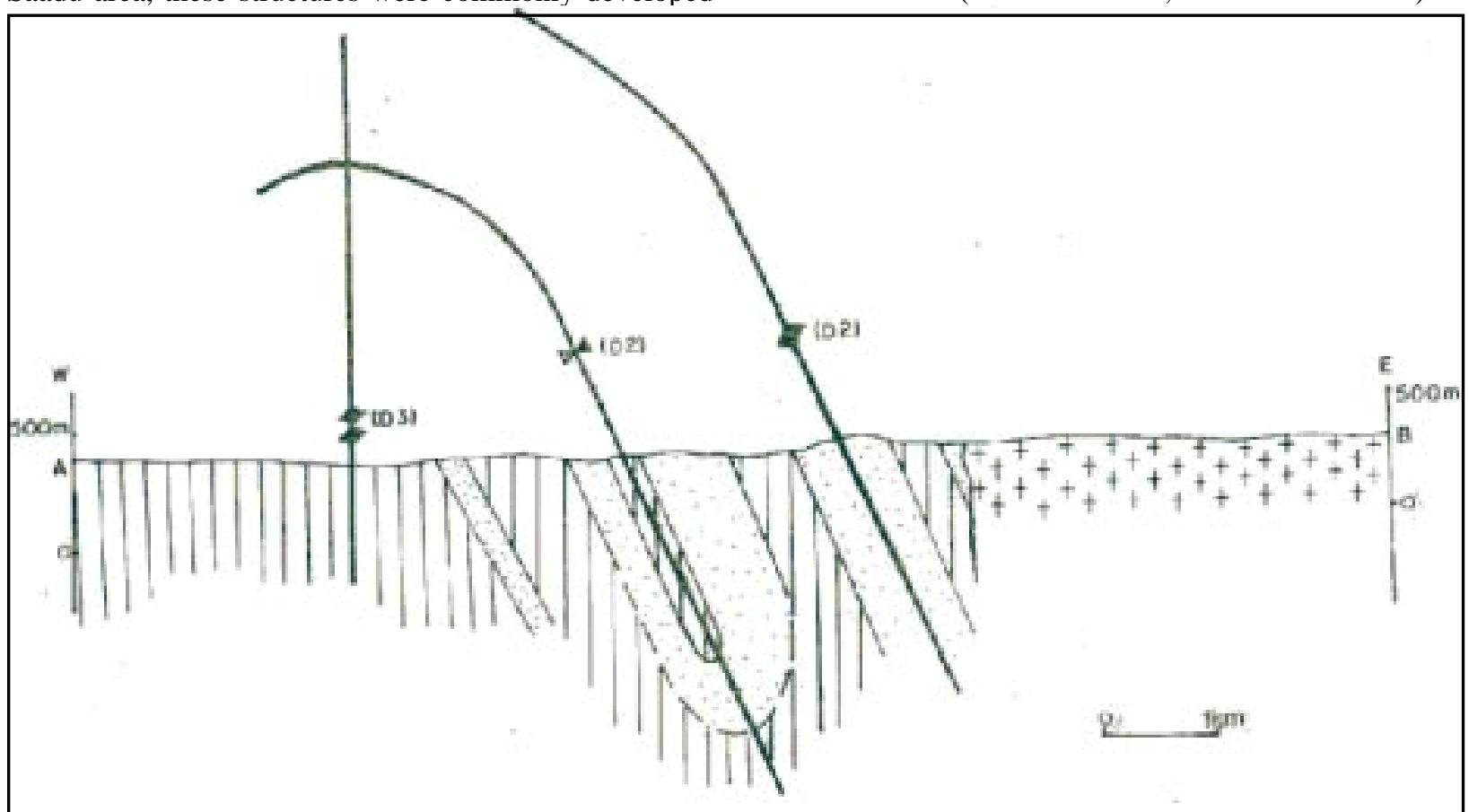

Fig. 7. 0W-E cross-section of the area showing the relationship of the early recumbent folds to the third phase Jebba-Bode Saadu antiform 
the Nigerian sector of the Pan-African mobile belt, lack of appropriate dates had not allowed the timing of these deformation events to be constrained with confidence.

\section{CONCLUSIONS}

1. Deformation in the Bode Saadu area was polyphasal, early ductile structures associated with orogenic contraction were followed by late brittle tectonics.

2. Early ductile deformation produced the regional tectonic fabric, S1, and tight to isoclinal minor folds.

3. Strain localization (heterogenous deformation) generated extensional ductile shears. This was followed by contractional faulting associated with recumbent folding.

4. These earlier structures were folded by the major D3 fold the Jebba-Bode Saadu antiform (Fig 7).

5. Late open folds crenulated earlier fabrics and deformed early pegmatitic dykes.

6. Late brittle tectonics involving conjugate strike-slip faulting occurred under sub-horizontal, approximately $\mathrm{N}-\mathrm{S}$ trending maximum compressive stress.

\section{ACKNOWLEDGEMENTS}

This paper is dedicated to the blessed memory of Ade Omotosho whose hospitality, support and encouragement made the Jebba project fruitful. I thank Messrs. J. Julius and F. Onyebuchi for cartographic and photographic support, respectively. I also thank Prof. A.E. Annor for a helpful review of the manuscript.

This research is supported by grants from the Senate Research Fund of the University of Ilorin.

\section{REFERENCES}

Alsop, G. I. 1994. Relationships between distributed and localized shear in the tectonic evolution of a Caledonian fold and thrust zone, northwest Ireland . Geol. Mag. 131: 123-136.

Annor, .A.E 1998. Structural and chronological relationship between the low grade Igarra schist and its adjoining Okene migmatite-gneiss terrain in the Precambrian exposure of S.W. Nigeria. J, Min . Geol. 34: 197-194

Annor A.E., S.B. Olobaniyi \& A. Mucke 1996 A note on the geology of Isanlu area in the Egbe-Isanlu schist belt, S.W. Nigeria. J.Min. Geol. 32: 47-51.

Bertrand, J.M.L., A. Michard, A.M. Boullier \& D.Dautel 1986 Structure and U.Pb geochronology, tectonic implications for the Hoggar shield- Prec. Res. 7: 349-376.
Boesse, J.M., O.O. Ocan \& M.A. Rahaman 1989 Lithology and the structure of the Ife-Ilesha area. (abstract) - the $25^{\text {th }}$ Annual Conf. Nig. Mining \& Geosc. Soc., Ibadan: 6-7.

Caby, R. 1989 Precambrian terranes of Benin-Nigeria and northeast Brazil and the Late Proterozoic south Atlantic fit- Geol. Soc. Am. Spec. pap. 230: 145 158.

Cooper, M. 1981 The internal geometry of nappes: criteria for models of emplacement. In K.R. Mc Clay and N. J. Price (eds), Thrust and Nappe tectonics. Geol. Soc. London Spec. publ. 9: 225 - 234.

Ekwueme, B.N. 1987. Structural orientations and Precambrian deformational episodes of Uwet area, Oban Massif, S.E. Nigeria. Prec. Res. 34: 269289.

Fitches, W.R., A.C Ajibade, I.G. Egbuniwe, R.W. Holt \& J.B. Wright 1985. Late Proterozoic schist belts and plutonism in N.W. Nigeria. J. Geol. Soc. London 142:319-337.

Ogezi, A.E.O. 1977. Geochemistry and geochronology of basement rocks north-western Nigeria. Unpub. Ph.D. Thesis, Leeds Univ. U.K.

Okonkwo, C.T. 1992a. Structural geology of basement rocks of Jebba area, Nigeria. J. Min Geol 28: 203 -209.

Okonkwo, C.T. 1992b. The petrology, geochemistry and origin of metamorphosed calc-silicate bands in the metasedimentary rocks of Upper Strathspey, Scotland. J. Min. Geol. 28: 325-331.

Okonkwo, C.T. 1995 Synsedimentary tectonics in the Proterozoic metasedimentary rocks of Bode Saadu area, S.W. Nigeria (abstract) $-31^{\text {st }}$ Annual Conf. Nig. Mining \& Geosc. Soc., Calabar: 5-6.

Okonkwo, C.T. 1996. Early recumbent folding and thrusting in the Jebba area, S.W. Nigeria abstract). $32^{\text {nd }}$ Annual Conf. Nig. Mining \& Geosc. Soc. Benin: 77.

Okonkwo C.T. \& J.A. Winchester 1995. Geochemistry and geotectonic setting of metaigneous rocks in Jebba area, S.W. Nigeria. Centrepoint (Science) 5: 139-155.

Oversby. V.M. 1975 Lead isotope study of aplites from the Precambrian rocks near Ibadan, south-western Nigeria. Earth Planet. Sci. Letters 27: 177 - 180.

Rahaman, M.A. 1988. Recent advances in the study of the basement complex of Nigeria. In: P.O. Oluyide, W.C. Mbonu, A.E. Ogezi., I.G. Egbuniwe, A.C. Ajibade and A.C. Umeji (eds). Precambrian Geology of Nigeria. Geol. Surv. Nigeria: 11-41.

Ramberg, H. 1981. The role of gravity in orogenic belts. In: K.R. McClay and N.J. Price (eds), Thrust and Nappe tectonics. Geol. Soc. London Spec. publ. 9: $125-140$. 
Ramsay, J.G., M. Casey \& R. Kligfield, 1983. Role of shear in development of Helvetic fold-thrust belt of Switzerland. Geology 11: 439-442.

Ramsay, J.G. \& M.I. Huber, 1987. Techniques of Modern Structural Geology, V.2. Folds and Fractures. Academic Press, London.

Sawyer, E.W \& P.Y.F. Robin 1986. The subsolidus segregation of layer parallel quartz-feldspar veins in greenschist to upper amphibolite facies metasediments. J. Met. Geol. 4: 237-260.

Van Breemen, O.,R. Pidgeon \& P. Bowden 1997. Age and isotopic studies of Pan-African granites from north-central Nigeria. Prec. Res. 4: 307-319.

Winchester, J.A. 1975. Epidotic calc-silicates of Arnipol type- a widely distributed minor sedimentary facies of the Moine assemblage, Scotland. Geol. Mag. 112;175-181. 